Care: Jurnal Ilmiah Ilmu Kesehatan Vol .8, No.2, 2020, hal 206-221

Tersedia online di https://jurnal.unitri.ac.id/index.php/care

ISSN 2527-8487 (online)

ISSN 2089-4503 (cetak)

\title{
PENGARUH KUALITAS PELAYANAN KESEHATAN DAN KEPUASAN PASIEN TERHADAP CITRA KLINIK "X" DI TUBAN
}

\author{
Andrianto $^{1)}$, Cahyo Sasmito ${ }^{2)}$, Cakti Indragunawan ${ }^{3)}$ \\ 1),2),3) Pascasarjana, Universitas Tribhuwana Tunggadewi Malang \\ E-mail: andre.andrita@yahoo.com
}

\begin{abstract}
This study aims to determine and analyze the effect of service quality and patient satisfaction on X Tuban clinical image. Sampling is done by simple random sampling. The number of samples determined was 92 samples. The data used are primary data and secondary data. The analytical method used to determine the effect of service quality and patient satisfaction on the X Tuban Clinic image is multiple linear regression with the Ordinary Least Square (OLS) method. Before a regression is carried out, a validity and reliability test is performed for each question. In addition, a normality test and a classic assumption test are performed. The results showed that the quality of service and patient satisfaction simultaneously and individually affected the positive image of the Tuban X Clinic.
\end{abstract}

Keywords: Health; image; satisfaction,; service; quality.

\begin{abstract}
ABSTRAK
Penelitian ini bertujuan mengetahui dan menganalisis pengaruh kualitas pelayanan kesehatan dan kepuasan pasien terhadap citra klinik X di Tuban. Pengambilan sampel dilakukan secara Simple Random Sampling. Jumlah sampel yang ditentukan sebanyak 92 sampel. Data yang digunakan yaitu data primer dan data sekunder. Metode analisis yang digunakan untuk mengetahui pengaruh kualitas pelayanan kesehatan dan kepuasan pasien terhadap citra klinik X adalah metode regresi linear berganda dengan metode Ordinary Least Square (OLS). Sebelum dilakukan regresi, dilakukan uji validitas dan reliabilitas terlebih dahulu dari setiap pertanyaan. Selain itu dilakukan uji normalitas dan uji asumsi klasik. Hasil penelitian menunjukkan bahwa kualitas pelayanan kesehatan dan kepuasan pasien secara simultan dan sendiri-sendiri berpengaruh terhadap citra Klinik X di Tuban secara positif.
\end{abstract}

Kata Kunci : Citra; kepuasan; kualitas; pelayanan; kesehatan.

Cara mengutip: Andrianto., Sasmito, Cahyo., \& Indragunawan, Cakti. (2020). Pengaruh Kualitas Pelayanan Kesehatan Dan Kepuasan Pasien Terhadap Citra Klinik "X” di Tuban. Care:Jurnal Ilmiah Ilmu Kesehatan, 8(2), 206-221 


\section{PENDAHULUAN}

Kesehatan merupakan hal yang sangat penting bagi manusia. Semakin banyak manusia yang semakin sadar akan pentingnya menjaga kesehatan tubuh, menjaga asupan makanan, olah raga, dan melakukan check up rutin di rumah sakit. Hal tersebut juga membuat fasilitas pelayanan publik misalnya rumah sakit, balai kesehatan, klinik, puskesmas dan lainnya berkembang dengan pesat dengan menyediakan berbagai fasilitas pendukung di bidang kesehatan. Semakin banyaknya jumlah rumah sakit serta klinik kesehatan berjalan seiring dengan semakin banyaknya masyarakat yang menggunakan fasilitas pelayanan kesehatan sehingga mengubah rumah sakit yang mulanya sebagai unit pelayanan publik yang bersifat sosial untuk kemanusiaan menjadi pelayanan kesehatan yang memiliki basis industri untuk kepentingan ekonomi (Adriansyah et. al., 2017 dan Nugraha et. al., 2017). Namun dari banyaknya fasilitas pelayanan kesehatan publik pasti memiliki kualitas pelayanan yang berbeda-beda, begitu pula dengan pandangan dan penilaian dari masyarakat. Hal tersebut yang membuat citra fasilitas pelayanan kesehatan publik berbeda-beda.
Dewasa ini, pengetahuan masyarakat mengenai kesehatan semakin luas sehingga mereka memiliki banyak pertimbangan untuk memilih fasilitas kesehatan yang tepat mulai dari fasilitas pelayanan yang baik dan lengkap sehingga rumah sakit, balai kesehatan, klinik maupun penyedia jasa fasilitas kesehatan lainnya berlomba-lomba meningkatkan kualitas dan pelayanan agar lebih baik dan mendukung kebutuhan masyarakat. Fasilitas kesehatan yang diberikan tidak hanya pelayanan untuk pengobatan dan penyembuhan penyakit namun juga pelayanan untuk pencegahan (preventif). Kepuasan pasien menjadi salah satu indikator untuk meningkatkan kualitas jasa kesehatan dan keberhasilan dalam penyelenggaraan pelayanan melalui citra yang baik dari masyarakat untuk fasilitas pelayanan publik tersebut.

Industri fasilitas pelayanan kesehatan masyarakat juga tidak jauh dari persaingan. Berbagai rumah sakit dan sejumlah klinik yang ada berusaha untuk memperoleh kepercayaan masyarakat dengan memberikan pelayanan yang berkualitas serta efisien. Fasilitas kesehatan umum di daerah adalah salah satu dari industri fasilitas pelayanan kesehatan, namun biasanya memiliki citra yang kurang baik dimata masyarakat 
dibandingkan dengan fasilitas pelayanan kesehatan swasta (Supartiningsih, 2017). Selain itu citra pelayanan kesehatan di Indonesia semakin meurun yang disebabkan karena masyarakat lebih berminat untuk berobat diluar negeri. Hal tersebut terjadi karena fasilitas dan kualitas layanan yang diberikan di luar negeri lebih baik (Yulianti \& Madiawati, 2015) sehingga kualitas pelyanan menajdi suatu hal yang sangat penting (Vigaretha et. al., 2018). Menurut Lupiyoadi (2006:148), kualitas pelayanan dilihat dari seberapa jauh perbedaan antara kenyataan dan harapan pelanggan atas layanan yang mereka terima atau peroleh, sehingga apabila layanan yang diterima atau dirasakan sesuai dengan harapan, maka layanan dipersepsikan baik oleh pelanggan, dan jika layanan yang diterima melampaui harapan pelanggan, maka kualitas pelayanan dikatakan ideal. Sebaliknya jika layanan yang diterima lebih rendah daripada yang diharapkan, maka kualitas pelayanan dipersepsikan buruk, untuk itu rumah sakit dituntut untuk dapat memberikan pelayanan kesehatan yang berkualitas secara konsisten.

Selain kualitas pelayanan kesehatan, kepuasan pasien juga sangat penting. Kepuasan pasien dapat dijelaskan sebagai perbedaan antara harapan dan kinerja yang dirasakan oleh pasien terhadap kinerja petugas rumah sakit dalam memberikan pelayanan, dimana jika kinerja dibawah harapan maka pasien akan kecewa, dan jika kinerja sesuai dengan harapan, pasien akan puas. Sedangkan bila kinerja melebihi harapan pasien akan merasa sangat puas (Supartiningsih, 2017). Oleh karena itu, kualitas pelayanan tidak hanya diukur dari segi materi yaitu berupa fasilitas yang mewah, kelengkapan teknologi serta penampilan fisik, namun juga dari sikap dan perilaku tenaga medis yang berkomitmen dan profesional yang juga akan mempengaruhi kepuasan pasien.

Klinik “ X” di Kabupaten Tuban merupakan salah satu klinik yang ada di Tuban. Klinik tersebut menyediakan pelayanan kesehatan untuk masyarakat. Klinik tersebut terus berupaya untuk meningkatkan kualitas layanan kesehatannya sehingga akan semakin banyak masyarakat percaya untuk berobatan di klinik tersebut. Klinik ini merupakan salah satu klinik yang memberikan jasa kesehatan diharapkan dapat memberikan pelayanan yang lebih berkualitas dan konsisten. Upaya-upaya pelayanan kesehatan bagi masyarakat memerlukan penyelesaian menyeluruh 
dan diperlukan penyusunan startegi serta tindak pelaksanaan pelayanan kesehatan yang baik dan berkualitas serta memberikan kepuasan terhadap pasien.

Kebijakan atau policy berkaitan dengan perencanaan, pengambilan, dan perumusan keputusan, pelaksanaan keputusan dan evaluasi terhadap dampak dari pelaksanaan keputusan tersebut terhadap orang banyak yang menjadi sasaran kebijakan (Marzali, 2012). Kriteria pengukuran keberhasilan implementasi menurut Ripley \& Franklin (1986) didasarkan pada tiga aspek, yaitu: (1) tingkat kepatuhan birokrasi terhadap birokrasi di atasnya atau tingkatan birokrasi sebagaimana diatur dalam undang-undang, (2) adanya kelancaran rutinitas dan tidak adanya masalah; serta (3) pelaksanaan dan dampak (manfaat) yang dikehendaki dari semua program yang ada terarah. Adanya suatu kebijakan pelayanan publik yang baik maka fasilitas pelayanan kesehatan dapat meningkatkan dan mempertahan kualitas serta menjaga kepuasan pelayanan kepada masyarakat, sehingga dapat membuat sebuah citra klinik kesehatan yang baik di mata masyarakat. Oleh sebab itu, penelitian ini penting dilakukan untuk mengetahui bagaimana citra Klinik X di Tuban dilihat dari kualitas pelayanan serta kepuasan pasien dari klinik tersebut. Penelitian mengenai kualitas pelayanan dan kepuasan pasien sudah cukup banyak dilakukan, namun dari spesifik lokasi tempat di klinik X Tuban belum ada yang meneliti sehingga harapannya dapat dijadikan bahan pertimbangan dalam merumuskan kebijakan di klinik tersebut dan melengkapi penelitian yang sudah ada sebelumnya.

\section{METODE PENELITIAN}

Penelitian ini dilakukan di Klinik X di Tuban dengan pengambilan sempel dilakukan secara Simple Random Sampling. Jumlah sampel yang ditentukan sebanyak 92 sampel. Data yang digunakan yaitu data primer dan data sekunder. Data sekunder diperoleh dari instansi atau lembaga terkait untuk memberikan tambahan informasi yang dibutuhkan oleh peneliti. Sedangkan data primer diperoleh dari responden wawancara. Wawancara dilakukan dengan kuesioner yang telah disiapkan untuk pasien atau pelanggan yang datang ke Klinik $\mathrm{X}$ di Tuban yang berisi daftar pertanyaan terbuka dan tertutup untuk menjaring informasi yang dibutuhkan dalam penelitian.

Metode analisis yang digunakan adalah regresi linear berganda dengan metode 
Ordinary Least Square (OLS). Sebelum dilakukan regresi, dilakukan uji validitas dan reliabilitas terlebih dari dari setiap pertanyaan. Selain itu dilakukan uji normalitas dan uji asumsi klasik dengan SPSS 23. Pada penelitian ini digunakan 3 persamaan yaitu persamaan untuk mengetahui pengaruh dari masing-masing variabel terhadap citra Klinik X di Tuban dan pengaruh kedua variabel terhadap citra Klinik X Tuban. Pengaruh kualitas pelayanan kesehatan dan kepuasan pasien terhadap citra Klinik X Tuban dapat ditulis sebagai berikut:

1) Pengaruh kualitas pelayanan kesehatan terhadap citra klinik X $Y=\alpha+\beta_{1} X_{1}+\mu$

Keterangan:

Y: Citra Klinik X di Tuban

$\alpha$ : konstanta

$\beta_{1}$ : koefisien regresi

$\mathrm{X}_{1}$ : Kualitas pelayanan kesehatan $\mu$ : error term

2) Pengaruh kepuasan pasien terhadap citra klinik 'X' Tuban

$$
Y=\alpha+\beta_{2} X_{2}+\mu
$$

Keterangan:

Y: Citra Klinik X di Tuban

$\alpha$ : konstanta $\beta_{2}:$ koefisien regresi

$\mathrm{X}_{2}$ : Kepuasan pasien

$\mu$ : error term

3) Pengaruh kualitas pelayanan kesehatan dan kepuasan pasien secara simultan terhadap citra Klinik $\mathrm{X}$ di Tuban

$$
Y=\alpha+\beta_{1} X_{1}+\beta_{2} X_{2}+\mu
$$

Keterangan:

Y: Citra Klinik X di Tuban

$\alpha$ : konstanta

$\beta_{1} \ldots \mathrm{n}$ : koefisien regresi

$\mathrm{X}_{1}$ : Kualitas pelayanan kesehatan

$\mathrm{X}_{2} \quad$ : Kepuasan pasien

$\mu$ : error term

\section{HASIL}

Pada Tabel 1 hasil perhitungan distribusi responden berdasarkan umur, dapat diketahui bahwa paling banyak responden berusia 45-49 tahun sebanyak 31 orang dengan persentase $33,70 \%$. Data responden berdasarkan pekerjaan menunjukkan bahwa paling banyak bekerja sebagai pegawai swasta dengan persentase $35,87 \%$, dan berdasarkan tingkat pendidikan jumlah responden paling banyak yaitu tingkat pendidikan sarjana dengan persentase 47,83\%. 
Tabel 1. Karakteristik Responden

\begin{tabular}{clcc}
\hline Keterangan & Kategori & $\mathrm{f}$ & $(\%)$ \\
\hline $20-24$ & 4 & 4.35 \\
& $25-29$ & 8 & 8.70 \\
Umur & $30-34$ & 1 & 1.09 \\
& $35-39$ & 8 & 8.70 \\
& $40-44$ & 15 & 16.30 \\
& $45-49$ & 31 & 33.70 \\
& $\geq 50$ & 25 & 27.17 \\
\hline \multirow{5}{*}{ Pekerjaan } & Ibu Rumah Tangga & 15 & 16.30 \\
& Mahasiswa & 4 & 4.35 \\
& Pegawai Negeri & 21 & 22.83 \\
& Pegawai Swasta & 33 & 35.87 \\
& TNI/Polri & 1 & 1.09 \\
& Wiraswasta & 18 & 19.57 \\
\hline \multirow{5}{*}{ Pendidikan } & SMA & 38 & 41.30 \\
& Diploma & 10 & 10.87 \\
& Sarjana & 44 & 47.83 \\
\hline
\end{tabular}

Pada Tabel 2 diketahui variabel kualitas layanan jawaban responden pada kategori Sangat Setuju (SS) sebesar 17,11\% dan kategori Setuju merupakan jawaban yang paling banyak dipilih oleh responden dengan persentase sebesar 56,86\%. Pada variabel kepuasan pasien dan citra klinik juga sama, pilihan jawaban responden paling banyak adalah Setuju dengan persentase secara berurutan yaitu 54,95\% dan $47,42 \%$. Dilihat dari sebaran jawaban responden dapat dilihat bahwa mayoritas responden setuju bawah Klinik $\mathrm{X}$ di Tuban memiliki kualitas layanan yang baik, serta pasien puas dengan layanan yang diberikan oleh klinik $\mathrm{X}$ di Tuban serta citra yang dimiliki oleh Klinik X di Tuban baik.

Tabel 2. Sebaran Kepuasan Responden

\begin{tabular}{lccccc}
\hline \multirow{2}{*}{ Variabel } & \multicolumn{5}{c}{ Kategori $(\%)$} \\
\cline { 2 - 6 } & STS & TS & N & S & SS \\
\hline Kualitas Layanan & 0.71 & 14.29 & 28.15 & 56.86 & 17.11 \\
Kepuasan Pasien & 0.12 & 5.31 & 16.06 & 54.95 & 23.55 \\
Citra Klinik & 0.14 & 3.94 & 17.26 & 47.42 & 31.25 \\
\hline
\end{tabular}

Berdasarkan Tabel 3 diketahui bahwa nilai adjusted $\mathrm{R}^{2}$ sebesar 0,250 atau $25 \%$. Hal tersebut menunjukkan bahwa 25\% variasi variabel dependen (citra klinik $\mathrm{X}$ di Tuban) dapat dijelaskan oleh variabel independen (kualitas layanan). Sisanya 
sebesar 75\% variasi variabel dependen dijelaskan oleh variabel lain di luar model. P-value uji F sebesar 0,000 (berada di bawah nilai 0,01 ) dan siginifikansi uji $\mathrm{t}$ sebesar $\quad 0,000$ sehingga variabel independent yaitu kualita pelayanan kesehatan berpengaruh signifikan terhadap citra Klinik X di Tuban dengan tingkat kepercayaan 99\%. Pada persamaan regresi nilai konstanta sebesar 2,302. Nilai tersebut menunjukkan apabila variabel independen dianggap nol, maka besarnya Citra Klinik X di Tuban sebesar 2,302. Hasil regresi menunjukkan bahwa citra klinik $\mathrm{X}$ di Tuban dipengaruhi oleh kualitas layanan secara positif dengan koefisien sebesar 0,482 .

Tabel 3. Hasil Uji Analisis Pengaruh Kualitas Pelayanan Kesehatan terhadap Citra klinik 'X' Tuban

\begin{tabular}{lcrc}
\hline Variabel & Koefisien & t-hitung & P-value uji t \\
\hline Konstanta & $2,302^{* * *}$ & 7,264 & 0,000 \\
Kualitas Pelayanan Kesehatan & $0,482^{* * *}$ & 5,591 & 0,000 \\
\hline R2 & & & 0,258 \\
Adjusted R2 & & & 0,250 \\
P-value uji F & & $31,258^{* * *}$ \\
Probability & & & $0,000^{* * *}$ \\
\hline Keterangan: & $* * *$ & $=$ signifikansi pada tingkat kepercayaan $99 \%$ & \\
& $* *$ & $=$ signifikansi pada tingkat kepercayaan $95 \%$ &
\end{tabular}

Tabel 4. Hasil Uji Analisis Pengaruh Kepuasan Pasien terhadap Citra Klinik X di Tuban

\begin{tabular}{lcrr}
\hline Variabel & Koefisien & t-hitung & P-value uji t \\
\hline Konstanta & $1,372^{* * *}$ & 3,801 & 0,000 \\
Kepuasan Pasien & $0,678^{* * *}$ & 7,488 & 0,000 \\
\hline R2 & & & 0,384 \\
Adjusted R2 & & & 0,377 \\
P-value uji F & & $56,075^{* * *}$ \\
Probability & & & $0,000^{* * *}$ \\
\hline Keterangan: & $* * *$ & $=$ signifikansi pada tingkat kepercayaan $99 \%$ & \\
& $* *$ & $=$ signifikansi pada tingkat kepercayaan $95 \%$ &
\end{tabular}

Pada Tabel 4 diketahui bahwa nilai adjusted $\mathrm{R}^{2}$ sebesar 0,377 atau $37,7 \%$. Hal tersebut menunjukkan bahwa $37,7 \%$ variasi variabel dependen (citra klinik $\mathrm{X}$ di Tuban) dapat dijelaskan oleh variabel independen (kepuasan pasien). Sisanya sebesar 62,3\% variasi variabel dependen dijelaskan oleh variabel lain di luar model. P-value uji F sebesar 0,000 (berada di bawah nilai 0,01 ) dan siginifikansi uji $\mathrm{t}$ sebesar 0,000 sehingga variabel independen berpengaruh signifikan 
terhadap terhadap citra Klinik $\mathrm{X}$ di Tuban dengan tingkat kepercayaan 99\%. Pada persamaan regresi nilai konstanta 1,372. Nilai tersebut menunjukkan apabila variabel independen dianggap nol, maka besarnya Citra klinik ' $X$ ' Tuban sebesar 1,372. Hasil regresi menunjukkan bahwa citra klinik $\mathrm{X}$ di Tuban dipengaruhi oleh kepuasan pasien secara positif dengan koefisien sebesar 0,678.

Pada Tabel 5 diperoleh hasil bahwa nilai adjusted $\mathrm{R}^{2}$ sebesar 0,465 atau $46,5 \%$. Hal tersebut menunjukkan bahwa 46,5\% variasi variabel dependen (citra klinik $\mathrm{X}$ di Tuban) dapat dijelaskan oleh variabel independen (kualitas layanan dan kepuasan pasien). Sisanya sebesar 53,5\% variasi variabel dependen dijelaskan oleh variabel lain di luar model. P-value uji $\mathrm{F}$ sebesar 0,000 (berada di bawah nilai 0,01) yang menunjukkan secara bersama sama variabel indepnden yaitu kualitas layanan dan kepuasan pasien mempengaruhi citra Klinim $\mathrm{X}$ di Tuban dengan tingkat kepercayaan 99\%. Siginifikansi uji $\mathrm{t}$ sebesar 0,000 pada kualitas pelayanan kesehatan maupun kepuasan pasien sehingga variabel independen berpengaruh secara masing-masing terhadap variabel dependen dengan tingkat dengan tingkat kepercayaan 99\%. Pada persamaan regresi nilai konstanta 1,372. Nilai tersebut menunjukkan apabila variabel independen dianggap nol, maka besarnya Citra Klinik X di Tuban sebesar 1,372. Hasil regresi menunjukkan bahwa citra klinik $\mathrm{X}$ di Tuban dipengaruhi oleh kepuasan pasien secara positif dengan koefisien sebesar 0,678.

Tabel 5. Hasil Uji Analisis Pengaruh Kualitas Pelayanan Kesehatan terhadap Citra Klinik X di Tuban

\begin{tabular}{lcrr}
\hline Variabel & Koefisien & t-hitung & P-value uji t \\
\hline Konstanta & $2,045^{* *}$ & 3,801 & 0,044 \\
Kualitas Pelayanan Kesehatan & $6,093^{* * *}$ & 7,488 & 0,000 \\
Kepuasan Pasien & $3,973^{* * *}$ & & 0,000 \\
\hline R2 & & 0,477 \\
Adjusted R2 & & 0,465 \\
P-value uji F & & $40,535^{* * *}$ \\
Probability & & $0,000^{* * *}$ \\
\hline Keterangan: $* * *$ & $=$ signifikansi pada tingkat kepercayaan $99 \%$ & \\
& $* *$ & $=$ signifikansi pada tingkat kepercayaan $95 \%$ &
\end{tabular}




\section{PEMBAHASAN}

Klinik yang dapat dijalankan secara optimal sesuai dengan fungsinya maka perlu dilakukan pengelolaan yang baik. Pengelolaan tersebut mulai dari sumberdaya yang digunakan, proses pelayanan hingga kinerja pelayanan. Masyarakat menginginkan pelayanan kesehatan yang baik, aman, bermutu, dan sesuai dengan kebutuhan masyarakat. Upaya peningkatan mutu, manajemen risiko dan keselamatan pasien perlu dilaksanakan dalam pengelolaan klinik dalam memberikan pelayanan kesehatan yang menyeluruh kepada masyarakat. Hal tersebut juga bertujuan untuk menjaga kepuasan pasien. Kualitas pelayanan kesehatan yang bermutu dan kepuasan pasien tidak lepas dengan citra suatu klinik. Jika kualitas pelayanan kesehatan bermutu dan kepuasan pasien baik maka citra klinik akan baik. Selain itu, kepuasan pasien dapat dijadikan tolok ukur keberhasilan klinik dalam mengembangkan citranya. Kepuasan pasien akan tercipta ketika apa yang didapat lebih besar dari yang diharapkan.

Hasil dari penelitian ini menunjukkan bahwa citra Klinik X di Tuban secara positif dipengaruhi oleh kualitas layanan kesehatan dan kepuasan pasien. Pada penelitian digunakan beberapa item pertanyaan yang menggambarkan karakteristik kualitas pelayanan. Masingmasing item pertanyaan mecerminkan beberapa indikator yang menggambarkan kualitas pelayanan yaitu bukti langsung, kehandalan, daya tanggap, dan empati. Hal tersebut juga sama dengan penelitian yang dilakukan oleh Adriansyah et al., (2017) dan Dewi (2016), yang menggunakan kelima indikator tersebut untuk menggambarkan kualitas pelayanan. Namun pada penelitian tersebut meneliti mengenai pengaruh kualitas pelayan dengan indikator bukti langsung, kehandalan, daya tanggap, jaminan, dan empati terhadap kepuasan pasien menunjukkan hasil bahwa indikator tersebut berpengaruh secara positif terhadap kepuasan pasien. Pada penelitian ini kualitas pelayanan dilihat dari seberapa besar perbedaan diantara kenyataan dengan harapan pelanggan atau pasien terhadap pelayanan yang diterima. Dengan indikator meliputi: 1) Bukti langsung: Penampilan gedung balai kesehatan dari luar cukup menarik dan dokter, perawat, serta tenaga non medis mengenakan pakaian dengan rapi. 2) Kehandalan: Ketepatan waktu dokter dalam memberikan pelayan serta dokter dan perawat memberikan pelayanan yang sama pada semua pasien tanpa membedakan sakit yang diderita. 3) Daya 
tanggap: Dokter segera memberikan konfirmasi setelah selesai pemeriksaan serta kesediaan dokter maupun perawat dalam memberikan pertolongan dalam setiap kali dibutuhkan. 4) Jaminan dan Kepastian: Dokter, perawat dan tenaga non medis memilki sikap yang sopan dalam memberikan pelayanan serta dokter dan perawat memiliki kemampuan yang baik dalam melakukan tindakan medis. 5) Empati: Dokter dan perawat mampu membuat nyaman pasien dan meluangkan waktu jika dibutuhkan.

Penelitian yang sudah dilakukan Febriani \& Andri (2015) hampir sama dengan penelitian ini yaitu mengenai pengaruh kualitas pelayan terhadap citra di Rumah Sakit Islam Ibnu Sina Pekanbaru. Pada penelitian tersebut juga dilakukan uji validitas serta reliabilitas kemudian dianalisis menggunakan analisis regresi liner berganda. Hasil penelitian tersebut menunjukkan bahwa kualitas pelayanan di rumah sakit tersebut dikategorikan baik karena sebagian besar pasien memberikan pernyataan yang baik terhadap kualitas pelayanan yang diberikan. Selain itu tanggapan dari responden perihal citra perusahaan juga baik. Berdasarkan hasil perhitungan kualitas pelayanan mempunyai pengaruh positif terhadap citra. Hasil penelitian Marzaweny et. al.,
(2012) juga menunjukkan hasil bahwa kualitas pelayanan kesehatan mempunyai efek yang positif terhadap citra rumah sakit. Pada penelitian tersebut sebesar 0,536 kualitas pelayanan kesehatan mempengaruhi citra rmah sakit secara positif yang berarti bahwa semakin tinggi kualitas pelayanan kesehatan yang diberikan, maka semakin baik pula citra rumah sakit. Begitu pula degngan penelitian yang dilakukan oleh Ayutika (2018) yang menunjukkan terdapat pengaruh yang signifikan antara kualitas layanan terhadap citra, dilihat dari segi fisik, daya tanggap karyawan rumah sakit, kemampuan dalam memberikan layanan yang diterima akan lebih meningkatkan citra rumah sakit. Ryu \& Han (2010) dalam penelitiannya mengenai pengaruh kualitas lingkungan fisik, makanan, dan pelayanan terhadap citra restoran, kepuasan dan perilaku pelanggan, membuktikan bahwa kualitas pelayanan berpengaruh positif dan signifikan terhadap citra restoran. Selain itu, hasil penelitian tersebut juga menunjukkan bahwa citra restoran memiliki pengaruh yang siginifikan dan positif terhadap kepuasan pelanggan. Hal tersebut menunjukkan bahwa kemajuan terhadap kualitas lingkungan fisik, makanan, dan pelayanan dapat meningkatkan citra restoran yang kemudian berdampaknya 
Care: Jurnal Ilmiah Ilmu Kesehatan Vol .8, No.2, 2020, hal 206-221

terhadap kepuasan pelanggan yang semakin meningkat.

Pelayanan yang memiliki kualitas baik dapat menimbulkan kesan baik kepada pelanggan yang kemudian apabila kualitas layanan tersebut dapat dipertahankan dan ditingkatkan maka akan melekat dimasyarakat bahwa perusahaan tersebut dipandang baik (Sharon \& Suryono Budi Santoso, 2017). Menurut Subagyo, (2010) hal hal yang dapat dilakukan untuk meningkatkan kualitas pelayanan kesehatan yaitu dengan mengedukasi pelanggan agar dapat memahami hak dan kewajibannya mengenai produk dan jasa, menjaga relasi jangkap panjang yang saling menguntungkan, menekankan pentingnya orientasi pada pelanggan, meningkatkan retensi pelanggan dengan memahami faktor yang menyebabkan pelanggan berpindah ke tempat lain, memberikan layanan yang lebih baik dibandingkan pesaing, memanfaatkan teknologi untuk meningkatan kualitas layanan, menangani komplain dengan efektif melalui empati terhadap pelanggan yang marah, cepat menangani ketika ada keluhan, dan sebagainya, selain itu perlu dilakukan evaluasi dan belajar dari setiap kegagalan produk atau layanan untuk peningkatan layanan kedepannya. kualitas pelayanan publik dan kinerja pelayanan kesehatan, kehandalan menjadi fokus utama yang perlu diperhatikan mengingat sesungguhnya kebutuhan dasar yang paling diinginkan para pasien pengguna jasa adalah kemampuan rumah sakit dalam memberikan layanan kesehatan yang akurat tanpa membuat kesalahan dari awal hingga akhir pelayanan dan penyampaian jasa yang tepat waktu dan sesuai dengan yang dijanjikan (Marlindawaty, 2018).

Selain kualitas pelayanan, pada penelitian ini juga melihat pengaruh kepuasan pasien terhadap citra klinik X di Tuban. Kepuasan pasien yaitu dilihat dari sikap pasien atau pelanggan setelah melakukan perawatan. Dengan indikator meliputi: 1) Hubungan harmonis: Dokter dan perawat memberikan pelayanan yang baik dan tulus serta membuat kesan yang baik untuk pasien. 2) Pembelian ulang: Pasien akan kembali lagi jika mengalami gangguan kesehatan di tempat yang sama. 3) Loyalitas: Pasien menjadikan rumah sakit sebagai tempat rujukan pertama dan alternatif utama jika mengalami gangguan kesehatan, 4) Word of Mouth: Pasien menyarankan dan memberikan rekomendasi kepada saudara, temankerabat yang mengalami gangguan kesehatan untuk datang ke rumah sakit 
tersebut, serta menjalani perawatan disana.

Kepuasan pasien muncul karena adanya kualitas yang merupakan point keberhasilan dalam fasilitas kesehatan misalnya rumah sakit, klinik, dan lainnya. Kepuasan pasien dapat dilihat dalam cakupan pengalaman secara keseluruhan dari pasien terhadap fasilitas kesehatan (Alrubaiee dan Alkaa'ida, 2011). Hal tersebut menunjukkan bahwa kepuasan pasien sangat penting karena dapat mempengaruhi citra klinik $\mathrm{X}$ di Tuban. Kepuasan pasien dapat dilihat dari berbagai aspek, salah satunya pendapat pasien dari mulut ke mulut. Jika pendapat pasien positif maka pasien dapat juga berperan sebagai penyebar informasi yang mendorong klinik memiliki citra yang baik.

Berdasarkan hasil penelitian yang disajikan Marzaweny et al., (2012), dapat diketahui bahwa kepuasan pasien memiliki pengaruh langsung dan positif terhadap citra RSUD Arifin Achmad Pekanbaru, dengan pengaruh sebesar 0,324. Ini berarti bahwa semakin tinggi kepuasan yang dirasakan oleh pasien, maka semakin baik pula citra RSUD Arifin Achmad Pekanbaru di mata masyarakat. Hal ini juga sesuai dengan penelitian yang dilakukan oleh Minkiewicz et. al. (2011) dan Ayutika (2018) yang membuktikan sebaliknya, bahwa citra perusahaan (corporate image) berpengaruh signifikan terhadap kepuasan pelanggan. Menurut Imran \& Ramil (2019) kepuasan pasien juga berpengaruh positif dan signifikan terhadap Citra Rumah Sakit dengan nilai t-value positif sebesar 2.479 yang siginifikan karena lebih besar dari t-tabel sebesar 1.96. Kepuasan pasien harus menjadi perhatian serius bagi rumah sakit maupun jasa fasilitas kesehatan lainnya untuk menaikkan citra lembaganya.

Menurut Hafizurrachman (2009) Upaya yang perlu dilakukan oleh pihak manajemen di suatu rumah sakit swasta di Tangerang untuk meningkatkan kepuasan pasien rawat jalan adalah dengan melakukan perbaikan terhadap indikator yang menurun dan mempertahankan terhadap indikator yang meningkat. Upaya untuk meningkatkan keramahan, kecepatan dan komunikasi bagi petugas dapat dilakukan dengan melakukan pelatihan (training) bagi petugas. Peningkatan kepuasan pasien sangat diperlukan untuk mempertahankan eksistensi sebuah pelayanan kesehatan agar dapat tetap bersaing. Apabila pasien merasa puas akan pelayanan yang 
diterima, maka akan memberikan manfaat bagi penyedia pelayanan tersebut salah satunya adalah kepuasan pasien dapat menimbulkan loyalitas

Menurut Wu (2011) citra rumah sakit akan mempengaruhi keputusan pasien dalam menikmati jasa layanan kesehatan yang mereka dapatkan. Dengan demikian, pemahaman mengenai hubungan diantara citra rumah sakit dan keinginan pelanggan untuk kembali menikmati jasa kesehatan yang sama sangat diperlukan. Citra rumah sakit memiliki fungsi yang sangat penting yaitu sebagai penghubung serta penjaga keharmonisan hubungan antara rumah sakit dengan pelanggan mereka Citra adalah kesan yang timbul karena pemahaman akan suatu kenyataan dengan satuan menggunakan skala likert.

Kebijakan pelayanan publik sangat diperlukan sebagai fasilitator untuk menjaga kualitas serta kepuasan pasien. Kebijakan sangat penting dalam memperkecil kegagalan dari suatu tujuan yang ingin dicapai. Menurut Howlett \& Ramesh (2003) menyatakan bahwa proses kebijakan publik terdiri dari lima tahapan yaitu (1) penyusunan agenda (agenda setting), (2) formulasi kebijakan (Policy Formulation), (3) pembuatan kebijakan (Decision Making), (4) implementasi kebijakan (Policy Implemetation), dan (5) evaluasi kebijakan (Policy Evaluation). Menurut Edwards (1980) implementasi suatu kebijakan dipengaruhi oleh empat variabel yang saling berhubungan satu sama lain, diantaranya komunikasi, sumber daya, sikap aparat pelaksana, dan struktur birokrasi.

Setiap kebijakan dapat dilaksanakan dengan baik apabila komunikasi yang terjadi efektif diantara pelaksana program (kebijakan) yaitu pihak pemberi fasilitas layanan kesehatan dengan para kelompok sasaran atau pasien. Apabila tujuan dan sasaran dari program atau kebijakan dapat disosialisasikan dengan baik maka distorsi kebijakan dan program dapat dihindari. Sumber daya yang memadai juga sangat penting, baik sumber daya manusia maupun sumber daya finansial. Sebab tanpa adanya sumber daya manusia yang profesional (tenaga medis dan non medis), kebijakan menjadi kurang baik dan berjalan lambat. Sedangkan sumber daya finansial menjamin keberlangsungan program atau kebijakan yang berangsung, misalnya fasilitas yang baik dan teknologi. Pelaksanaan kebijakan atau program juga harus diikuiti dengan keinginan atau tekat para pelaksana dalam melaksanakan dan menerapkan progra atau kebijakan agar tujuan dapat tercapai. Diperlukan pula 
suatu sistem birolrasi untuk mengendalikan dan mengkoordinir sumber daya agar tujuan organisasi dapat tercapai. Mekanisme implementasi program biasanya sudah ditetapkan melalui standar operating procedur (SPO) yang dicantumkan dalam guideline program/kebijakan. Setelah program atau kebijakan dapat dijalankan maka adanya evaluasi penting untuk mengetahui tingkat keberhasilan program dan bagian apa yang perlu diperbaiki dan ditingkatkan.

Dengan demikian kepuasan pelanggan selama meenggunakan jasa layanan kesehatan sangat penting selain itu kualitas layanan juga akan mempengaruhi perilaku pelanggan untuk mengambil keputusan terutama dalam menciptkan citra jasa layanan kesehatan. Pelanggan akan cenderung setia dan bertahan terhadap pilihannya apabila jasa layanan kesehatan mampu memberikan kualitas pelayanan terbaik dan pelanggan merasakan penawaran-penawaran pelayanan yang baik dari segi mutu pelayanan, produk serta kinerja (Yunida \& Wijaya, 2016).

Kebutuhan akan kesehatan sangat penting bagi manusia sehingga fasilitas kesehatan harus terjamin. Pelayanan kesehatan tidak dapat hanya standar bahkan dibawah standar sehingga kualitas kesehatan harus dijaga. Kesehatan masyarakat berhubungan dengan banyak hal karena mempengaruhi aktvitas. Oleh karena itu Klinik harus memiliki pelayan kesehatan yang baik agar dapat mewujudkan masyarakat yang sehat dan mempertahankan eksistensinya atau citranya di lingkungan masyarakat. Kepuasan pasien harus dijaga, dipertahankan, dan ditingkatkan karena masyarakat pasti menginginkan pengobatan yang terbaik untuk menjaga kesehatannya.

\section{KESIMPULAN}

Hasil penelitian menunjukkan bahwa ada pengaruh signifikan kualitas pelayanan terhadap citra klinik $\mathrm{X}$ di Tuban, ada pengaruh siginifikan kepuasan pasien terhadap citra klinik X di Tuban, dan ada pengaruh siginidfikan kualitas pelayanan dan kepuasan pasien terhadap citra klinik $\mathrm{X}$ di Tuban. Untuk meningkatkan citra Klinik X di Tuban maka kualitas pelayanan serta kepuasan pasien perlu ditingkatkan. Kualitas pelayanan dapat ditingkatkan dengan cara memberikan pelayanan yang profesional, menangani komplain dan masukan dengan efektif, memanfaatkan teknologi untuk meningkatkan kualitas layanan, dan selalu 
melakukan evaluasi. Sedangkan kepuasan konsumen dapat ditingkatan dengan melakukan perbaikan terhadap indikator yang menurun dan mempertahankan indikator yang meningkat.

\section{REFERENSI}

Adriansyah, Bahri, S., \& Santi, I. N. (2017). Kualitas pelayanan terhadap kepuasan pasien di RSUD Morowali Kecamatan Bungku Tengah. Jurnal Ilmu Manajemen Univesitas Tadulako, 3(2), 135-144.

Alrubaiee, L. (2011). The Mediating Effect of Patient Satisfaction in the Patients' Perceptions of Healthcare Quality - Patient Trust Relationship. International Journal of Marketing Studies, 3(1), 103-127. https://doi.org/10.5539/ijms.v3n1p 103

Ayutika, R. D. N. (2018). Pengaruh kualitas layanan dan kepuasan konsumen terhadap citra perusahaan. Seminar Nasional Dan Call For Paper III, (2005), 386-391.

Azwar, S. (1999). Reliabilitas dan Validitas. Yogyakarta: Pustaka Pelajar.

Dewi, M. (2016). Pengaruh kualitas pelayanan terhadap kepuasan pasien penggunan BPJS pada Rumah Sakit Rehabilitasi Medik Kabupaten Aceh Timur. Jurnal Manajemen Dan Keuangan, 5(2), 535-544.

Edwards, G. C. (1980). Implementing Public Policy. Washington: Congressional Quaterly Press.

Febriani, F., \& Andri, S. (2015). Pengaruh kualitas pelayanan terhadap citra perusahaan. Jom FISIP, 2(2), 1-8.

Hafizurrachman. (2009). Kepuasan Pasien dan Kunjungan Rumah Sakit. Jurnal Kesehatan Masyarakat Nasional, 4(1), 10-17.

Howlett, M., \& Ramesh. (2003). Studying Public Policy. New York: Oxford
University Press.

Imran, B., \& Ramil, A. H. (2019). Kepuasan pasien, citra rumah sakit dan kepercayaan pasien di Provinsi Sulawesi barat. Prosiding Seminar Nasional Pakar Ke 3, 2, 1-7.

Marlindawaty. (2018). Analisis kualitas pelayanan kesehatan publik di Rumah Sakit Khusus Berslin (RSKB) Sayang Ibu Balikpapan. Jurnal Eksekutif, 15(1), 147-177.

Marzali, A. (2012). Antropologi dan Kebijakan Publik. Jakarta: Prenada Media.

Marzaweny, D., Hadiwidjojo, D., \& Chandra, T. (2012). Analisis kepuasan pasien sebagai mediasi pengaruh kualitas pelayanan kesehatan terhadap citra Rumah Sakit Umum Daerah ( RSUD ). Jurnal Aplikasi Manajemen, 10(3), 564-573.

Minkiewicz, J., Brdson, K., Evans, J., \& Mavondo, F. (2011). Corporate image in the leisure service sector. Journal of Service Marketing, 25(3), 190-201.

https://doi.org/10.1108/088760411 11129173

Muchlis, M., \& Dewanto, A. (2011). Pengaruh kepercayaan, kepuasan pelanggan dan komitmen hubungan terhadap citra Rumah Sakit di Kota Blitar. Jurnal Aplikasi Manajemen, 11(66), 469-480.

Nugraha, N. M., Anwar, A., Priadana, M. S., \& Firdaus, O. M. (2017). Analisis pengaruh citra dan kualitas layanan terhadap kepuasan pasien serta implikasinya pada komunikasi pemasaran di Rumah Bersalin Fatimah Kota Bandung. Jurmal Teknologi Dan Manajemen Industri, 3(1), 14-19.

Ripley, R. B., \& Franklin, G. A. (1986). Policy Implementation and Bureaucracy. Homewood: The Dorse Press.

Ryu, K., \& Han, H. (2010). Influence of 
the quality of food, service, physical environment on customer satisfaction and behavioral intention in quick-casual restaurant: Moderating role of perceived price. Journal of Hospitality \& Tourism Research, 34(3), 310-329. https://doi.org/10.1177/109634800 9350624

Sharon, L. G., \& Suryono Budi Santoso. (2017). Analisis pengaruh kualitas layanan, fasilitas, citra rumah sakit, kepuasan pasien dalam rangka meningkatkan loyalitas pasien (Studi pada pasien rawat inap RSUD Tugurejo Semarang). Diponegoro Journal of Management, 6(3), 1-12.

Subagyo, A. (2010). Marketing in Business. Jakarta: Wacana Mitra Media.

Supartiningsih, S. (2017). Kualitas pelayanan kepuasan Pasien Rumah Sakit : Kasus Pada Pasien Rawat Jalan. Jurnal Medicoeticolegal Dan Manajemen Rumah Sakit, 6(April), 915.

https://doi.org/10.18196/jmmr.612 2
Vigaretha, G., Woro, O., \& Handayani, K. (2018). Peran kepuasan pasien sebagai variabel mediasi pengaruh mutu pelayanan terhadap loyalitas pasien. Higeia Journal of Public Health, 2(4), 543-552.

Wu, C. (2011). The impact of hospital brand image on service quality , patient satisfaction and loyalty. African Journal of Business Management, 5(12), 4873-4882. https://doi.org/10.5897/AJBM10.1 347

Yulianti, N., \& Madiawati, P. N. (2015). Pengaruh kualitas pelayanan terhadap kepuasan pasien pada unit rawat inap Rumah sakit Dr. hasan Sadikin Bandung. E-Proceeding of Management, 2(2), 2056-2065.

Yunida, M. E., \& Wijaya, T. (2016). Pengaruh citra rumah sakit dan kualitas pelayanan terhadap loyalitas pelanggan melalui kepuasan pelanggan di Rumah Sakit Amal Sehat Wonogiri. Universitas Negeri Yogyakarta, 287-297. 